\title{
Model Komunikasi Manajemen Konflik Perkawinan Campuran (Studi Kasus pada Pasangan Suami Istri Berbeda Kewarganegaraan)
}

\section{Communication Model of Mixed Marriage Conflict Management (Case Study of Couples Different Nationality)}

\author{
Luthfie Yanuar Werdyanto* \& Mohammad Kevin \\ International Communication for Business and Development, \\ London School of Public Relation, Indonesia
}

Diterima: 08 April 2020; Disetujui: 01 Mei 2020; Dipublish: 01 Juli 2020

\begin{abstract}
Abstrak
Penelitian ini dilatarbelakangi oleh fenomena yang terjadi saat ini dimasyarakat Indonesia yakni menikah lintas bangsa. Tujuan penelitian ini yaitu untuk mengetahui konflik yang terjadi dalam perkawinan campuran dan cara memanajemen konflik dari berbagai masalah yang muncul. Pendekatan yang digunakan adalah kualitatif bersifat studi kasus. Subjek utama adalah dua pasangan pernikahan beda kewarganegaraan serta informan pendukung adalah dua asisten rumah tangga pasangan pernikahan beda kewarganegaraan. Hasil dari penelitian diketahui bahwa masing-masing pasangan berbeda kewarganegaraan memiliki model komunikasi yang mampu digunakan untuk memanajemen konflik yang sedang timbul. Ketika ada konflik mereka akan saling mengidentifikasi masalah yang melanda, lalu mereka akan saling memberikan solusi untuk menyelesaikan masalah tersebut, selanjutnya mereka akan membuat komitmen agar konflik tidak kembali terjadi. Mereka sudah merasakan konflik yang sangat rumit untuk diselesaikan, namun mereka masih bisa melanjutkan pernikahan mereka dengan mengenyampingkan sementara konflik yang pelik tersebut.

Kata Kunci: Model komunikasi, pasangan beda kewarganegaraan, resolusi konflik
\end{abstract}

\begin{abstract}
This research was motivated by the phenomenon that is currently occuring in todays Indonesian society that is marriage across the nation. The purpose of this study were to understand the conflicts that occur within mixed marriage and how to manage conflict from various problems that arise. The employedapproach is qualitative case study. The main subjects are two married couples of different nationalities as well as supporting informants that consists of two Household Assistants marriage couples with different citizenship. The results of the research note that each pair of different citizenship has a communication model that can be used to manage conflict that is arising. When there is a conflict they will identify each other's problems, then they will give each other solutions to solve the problem, then they will make a commitment to the conflict so that it does not happen again. They already feel a very complicated conflict to resolve, but they can still continue their marriage by putting aside such complicated matters.
\end{abstract}

Keywords: Communication models, different citizenship, conflict resolution

How to Cite: Werdiyanto, L.Y. \& Kevin, M. (2020). Model Komunikasi Manajemen Konflik Perkawinan Campuran (Studi Kasus pada Pasangan Suami Istri Berbeda Kewarganegaraan). PERSPEKTIF, 9(2): 354-365

*Corresponding author:

ISSN 2085-0328 (Print)

E-mail: vanuarluthfie21@gmail.com

ISSN 2684-9305(Online) 


\section{PENDAHULUAN}

Globalisasi yang sudah berkembang sangat pesat ini individu tidak hanya dengan mudah untuk berkomunikasi dengan individu lain yang memiliki latar belakang budaya atau kebangsaan yang sama namun juga dapat melakukan komunikasi yang terbilang cukup jauh hingga ke mancanegara. Oleh karenanya banyak juga individu yang memiliki hubungan baik dengan individu lainya yang memiliki latar belakang budaya dan kebangasaan berbeda hingga berujung kepada proses pernikahan

Dalam perkawinan campuran tidak menutup kemungkinan terjadinya sebuah konflik. Konflik dapat terjadi baik dalam pernikahan yang harmonis maupun tidak harmonis, namun baik buruknya pengelolaan konflik tergantung pada kedua belah pihak (suami dan istri) (Dildar, Sitwat, \& Yasin, 2013). Jika keduanya saling membantu dan bekerja sama, penyelesaian konflik akan lebih mudah dan cepat selesai. Namun bila keduanya tidak memperdulikan permasalahan yang ada, bisa jadi pernikahan mereka berujung pada perceraian. Konflik sendiri berarti ketidakccocokan antar individu atau kelompok dalam memandang sesuatu hal dan diwujudkan dalam perilaku yang tidak sesuai dengan keinginan pihak lain yang terlibat untuk mencapai hasil atau suatu tujuan.

Perkawinan campuran dapat dijelaskan sebagai hubungan yang terjadi antara laki-laki dan perempuan yang memiliki latar belakang yang berbeda, seperti perbedaan budaya, dan bahasa. Perkawinan campuran rentan sekali terhadap yang namanya konflik karena didalam kehidupan sehari-harinya terdapat banyak perbedaan yang mudah memicu konflik.

Perkawinan campuran pasti terdapat banyak perbedaan, diantaranya perbedaan budaya. Perbedaan budaya tersebut akan mudah menghasilkan persoalan komunikasi seperti masalah norma-norma yang sudah melekat di tiap individu didalam pernikahan tersebut, yang akan menjadikan munculnya masalah miss communication. Didasari dari norma yang sudah melekat, masing-masing individu akan berlomba untuk menampilkan ciri khas budaya yang dimiliki.

Melihat dari penelitian terdahulu, banyak potensi konflik yang dapat muncul, diantaranya menurut Lainiala and Säävälä (2013) potensi konflik yang diteliti diantaranya agama, ras, kelompok etnis, kebangsaan, bahasa, kelas sosial, atau grup pendidikan. Menurut Zhang \& Van Hook (2009) konflik yang diteliti adalah perbedaan pendidikan, ras atau etnis dan agama. Penelitian ini berfokus pada konflik yang disebabkan oleh perbedaan latar belakang kebangsaan dalam konteks pernikahan. Menurut penjelasan dari National Healthy Marriage Resource Center (2009) dijelaskan potensinya dikarenakan tekanan dalam persamaan pendapat dari latar belakang yang berbeda serta penerimaan dari keluarga dan masyarakat luas. Berdasarkan beberapa penelitian di atas, terdapat beberapa potensi konflik yang dapat terjadi diantaranya adalah perbedaan agama, ras atau etnis, kebangsaan, bahasa, kelas sosial, nilainilai, pendidikan, penerimaan dari sudut pandang keluarga dan masyarakat luas.

Berdasarkan penelitian Pue and Sulaiman (2013) manajemen konflik dengan masalah yang dihadapi tidak berasal dari internal melainkan dari sumber eksternal seperti aturan sosial yang sudah berakar di masyarakatnya. Hal tersebut dilakukan oleh pasangan suami istri yang menjalani perkawinan campuran sehingga para pasangan perkawinan campuran dapat mempertahankan perkawinannya sampai dengan saat ini. Penelitian ini menggunakan metodologi kualitatif yang pengumpulan datanya dengan in-depth dan focus group interviews yang melibatkan lima puluh responden pelaku perkawinan campuran. Responden 
dipilih dan di identifikasi menggunakan teknik snowball. Hasil dari penelitian ini menunjukkan bahwa pernikahan campuran walaupun dapat memberi banyak keuntungan dalam penyatuan sosial antar etnis tetap memiliki banyak tantangan yang berasal dari eksternal seperti orang tua, keluarga, tetangga, masyarakat dan hukum. Hal yang membedakan penelitian Pue et al. dengan penelitian ini adalah dari konflik yang ditelitinya. Penelitian Pue et al. lebih menekankan bahwa konflik banyak terjadi dari faktor eksternal sedangkan penelitian ini lebih fokus ke bagian internal.

Sedangkan penelitian Morris (2003) memiliki tujuan untuk melihat perkawinan beda ras merasakan keterasingan dan menentukan bahwa persepsi keterasingan itu ada atau tidak, apabila ada bagaimana mereka mempengaruhi pasangannya untuk tidak mempercayai keluarganya dan bagian dari masyarakat sekitar mereka. Penelitian ini menggunakan riset deskriptif narasi bersamaan dengan indepth interviews kepada narasumber yang pernah dan sedang berkecimpung di perkawinan campuran. Hasilnya, perbedaan ras kulit putih dan hitam masih ada bersamaan dengan penolakan dari perkawinan campuran namun perkawinan ini tetap terus meningkat karena sudah memiliki undang-undang hak sipil dan hak ini mempengaruhi mereka dengan meningkatnya kesempatan untuk interaksi sosial dalam pendidikan dan lapangan pekerjaan. Hal yang membedakan penelitian Morris dengan penelitian ini adalah subjeknya. Penelitian oleh Morris subjeknya adalah pasangan suami istri yang sama warga negaranya namun berbeda rasnya, sedangkan penelitian ini subjeknya berbeda kewarganegaraan serta berbeda ras juga.

Selanjutnya adalah penelitian yang dilakukan oleh Esere (2003) bertujuan untuk untuk membahas teori resolusi konflik dalam perkawinan. makalah ini mengidentifikasikan penyebab konflik dan dampak yang di timbulkan terhadap perkawinan. Makalah ini menyoroti perilaku yang mengikat sebagai teknik resolusi konflik perkawinan. Penelitian ini menggunakan studi pustaka sebagai metodologi penelitiannya. Hasilnya, Ketidakstabilan dalam pernikahan dan dampak yang dihasilkan pada semua anggota keluarga adalah salah satu masalah yang paling berat untuk dihadapi masyarakat saat ini. Dengan demikian, untuk mengedukasikan pasangan dengan berbagai keterampilan untuk memanajemen konflik penting bagi kesehatan, kesejahteraan, dan untuk hidup berdampingan secara damai. Bagian pembeda antara penelitian Esere dengan penelitian ini adalah fokus penelitiannya. Penelitian yang dilakukan Esere lebih fokus kepada teori manajemen konfliknya sedangkan penelitian ini berpusat pada pola komunikasi dalam memanajemen konflik.

Terakhir penelitian yang dilaksanakan oleh Lewis (2013) memiliki tujuan untuk mengeksplorasi persepsi masalah kritis sosial yang berdampak pada pernikahan campuran di Amerika Serikat. Penelitian ini menggunakan pendekatan kualitatif berdasarkan pertanyaanpertanyaan tebuka di survey kuisioner yang diberikan kepada sampel tidak acak secara nasional untuk individu yang menikah antarras di tahun 2007. Hasil yang ditemukan dalam studi ini memberikan informasi berharga mengenai isu-isu utama yang dihadapi pernikahan antarras di Amerika Serikat. Perlakuan berbeda, persepsi negatif dari masyarakat, dan kurangnya penerimaan sosial dipandang sebagai tiga isu utama yang dihadapi pernikahan antarras. Akibatnya, sejumlah pasangan antar-ras melihat kelompok mereka dengan pandangan terpinggirkan oleh beberapa bagian masyarakat. Perbedaan dari penelitian yang dilakukan oleh Lewis dengan penelitian ini adalah metode penelitiannya. Metode penelitian yang dilakukan oleh 
Lewis adalah metode kuantitatif dengan survey kuisioner secara terstruktur sedangkan penelitian ini menggunakan metode kualitatif yang bersifat studi kasus.

Tidak sedikit pasangan suami istri yang melakukan perkawinan campuran selalu berakhir tragis seperti perceraian, namun banyak juga yang umur pernikahannya panjang bahkan hingga salah satu dari suami maupun istri yang terlibat dalam pernikahan tersebut tutup usia. Karena kunci utama dalam panjangnya umur perkawinan entah itu perkawinan yang sama negaranya ataupun perkawinan berbeda kewarganegaraan terdapat pada lancarnya komunikasi yang dilakukan dalam hubungan suami istri tersebut. Ada cara yang cukup efisien dalam memanajemen konflik yaitu assessment, acknowledgement, attitude, action dan analysis(Borisoff \& Victor, 1989).Dengan memahami lima tahap tersebut diharapkan dapat meningkatkan kesadaran konflik dikedua belah pihak dan mudah-mudahan dapat menangani konflik dengan lebih baik.

Saat ini peneliti menemukan permasalahan yang terjadi pada suatu keluarga yang berbeda kewarganegaraannya. Dimana permasalahan tersebut dianggap wajar oleh lingkungan sekitar namun tidak menurut sudut pandang peneliti. Berdasarkan pengamatan yang dilakukan terhadap subjek, peneliti melihat adanya konflik yang terjadi antara suami dengan keluarga istri yang terjadi pada saat pertemuan keluarga dan suami terlihat terasingkan karena perbedaan bahasa dan budaya dari pihak keluarga istri, namun disini peneliti tidak melihat adanya tekanan yang dirasakan oleh suami. Kemudian peneliti mencoba untuk berinteraksi dengan subjek dan menanyakan apa yang membuat subjek terlihat terasingkan oleh pihak keluarga istri. Menurut penjelasan subjek, subjek tidak merasa terasingkan namun tidak mengerti dan tidak tahu apa yang harus dilakukan ketika ada pertemuan keluarga.

Setelah melaksanakan observasi singkat secara verbal yang didapatkan dari beberapa KUA di kota Bandung tingkat pernikahan campuran setiap tahunnya tidak menentu dan tidak ditemukan kenaikan angka yang signifikan. Ini menunjukan bahwa pernikahan campuran di kota Bandung masih menjadi hal yang langka. Menurut Zhang and Van Hook (2009) mengapa hal ini patut diteliti karena di Amerika Serikat penduduknya yang tumbuh secara beragam, penting untuk memperbaharui penelitian sebelumnya termasuk perkawinan campuran yang melibatkan orang Asia dan Hispanik.

Tujuan dari penelitian ini adalah untuk mengetahui konflik yang terjadi dalam perkawinan campuran, selanjutnya adalah untuk mengetahui komunikasi dalam memanajemen konflik di perkawinan campuran dan yang terakhir adalah untuk mengetahui alasan mengapa konflik dapat terjadi dalam perkwainan campuran.

\section{METODE PENELITIAN}

Pada penelitian ini peneliti melakukan metode kualitatif yang bersifat studi kasus. Pendekatan kualitatif adalah penelitian yang bermaksud untuk memahami fenomena tentang apa yang dialami oleh subjek penelitian, misalnya perilaku, persepsi, motivasi dan lain sebagainya (Moleong, 2011). Dalam pendekatan kualitatif ini yang akan dikumpulkan berupa tanggapan, pendapat, konsep dan keterangan yang berbentuk uraian guna mengungkapkan masalah. Peneliti menggunakan metode kualitatif dikarenakan dalam mendeskripsikan dan menginterpretasikan informan dapat diteliti secara mendalam juga terfokus, serta sangat efektif dalam mencari tanggapan dan pandangan karena bertemu dengan informannya secara langsung. 
Alasan mengapa menggunakan studi kasus karena peneliti dapat menggali informasi dari pertanyaan-pertanyaan umum yang dapat dibentuk menjadi mengerucut agar fokus penelitiannya menjadi lebih mendetail yang akhirnya bisa dipelajari atau ditarik dari sebuah kasus. Saat memilih kasusnya pun peneliti mempertimbangkan bahwa dari kasus tersebut akan memperoleh pengetahuan Tabel 1 Pengumpulan Data

\begin{tabular}{|c|c|c|}
\hline $\begin{array}{l}\text { Teknik } \\
\text { Pengumpulan Data }\end{array}$ & Aspek Penelitian & Sumber Data \\
\hline $\begin{array}{l}\text { Wawancara Semi- } \\
\text { Terstruktur }\end{array}$ & $\begin{array}{l}\text { Untuk mengetahui cara meyelesaikan } \\
\text { konflik terkait dengan apa saja konflik yang } \\
\text { terjadi dalam rumah tangga pasangan beda } \\
\text { kewarganegaraan. Bagaimana cara resolusi } \\
\text { konflik dan gaya penyelesaian konflik yang } \\
\text { digunakan oleh para pelaku pernikahan } \\
\text { beda kewarganegaraan, }\end{array}$ & $\begin{array}{l}\text { Informan Pasangan } 1 \\
\text { TJL ( } 45 \text { tahun) } \\
\text { ND ( } 44 \text { tahun) } \\
\text { Informan Pasangan } 2 \\
\text { TM ( } 64 \text { tahun } \\
\text { AI ( } 45 \text { tahun) } \\
\text { Informan Tambahan (ART) } \\
\text { BL ( } 40 \text { tahun) } \\
\text { MT ( } 60 \text { tahun) }\end{array}$ \\
\hline Observasi & $\begin{array}{l}\text { Melihat proses komunikasi yang terjalin } \\
\text { padapasangan pernikahan berbeda } \\
\text { kewarganegaraan, dan menyamakan hasil } \\
\text { wawancara dengan pengamatan }\end{array}$ & $\begin{array}{l}\text { Informan Pasangan } 1 \\
\text { TJL ( } 45 \text { tahun) } \\
\text { ND ( } 44 \text { tahun) } \\
\text { Informan Pasangan } 2 \\
\text { TM ( } 64 \text { tahun } \\
\text { AI ( } 45 \text { tahun) } \\
\text { Informan Tambahan (ART) } \\
\text { BL ( } 40 \text { tahun) } \\
\text { MT ( } 60 \text { tahun) }\end{array}$ \\
\hline Studi Dokumentasi & $\begin{array}{l}\text { Data mengenai kisah hidup, riwayat } \\
\text { pernikahan dan biografi informan }\end{array}$ & $\begin{array}{l}\text { Hasil dari wawancara secara } \\
\text { informal tanpa harus bertemu } \\
\text { secara tatap muka serta } \\
\text { pengamatan secara langsung } \\
\text { terhadap informan di lapangan. }\end{array}$ \\
\hline
\end{tabular}

Alasan mengapa memilih informan utama diatas dikarenakan mereka memiliki kriteria sebagai berikut: 1) Berbeda kewarganegaraan; Memiliki komitmen marriage-like(Holt, 2004): 1) Sudah memiliki hubungan yang cukup lama; 2) Kohabitasi, atau tinggal bersama dalam satu rumah; 3) Menanggung tanggung jawab financial dan legal bersama-sama; 4) Hubungan yang diakui secara sosial oleh lingkungan.

HASIL DAN PEMBAHASAN

Konflik yang Dihadapi oleh Pasangan Beda Kewarganegaraan

Identitas budaya dalam bentuk perilaku keseharian masing-masing lebih lanjut dan mendalam secara ilmiah. Dalam hal ini peneliti ingin memperoleh informasi dan pengetahuan lebih yang terkait dengan resolusi konflik dalam pernikahan berbeda kewarganegaraan.

Subjek dalam penelitian ini adalah dua pasangan suami istri berbeda kewarganegaraan dan dua asisten rumah tangga sebagai informan tambahan dengan pengumpulan datanya sebagai berikut: terhadap informan di lapangan.

individu yang berbeda. Temuan yang sudah dikumpulkan oleh peneliti terdapat dua macam terkait dengan identitas budaya, konflik yang ringan dan konflik berat. Perilaku disiplin dalam keseharian, tepat waktu, dan selera makan masuk ke bagian jenis konflik ringan sedangkan dari konflik yang beratnya ada penentuan kewarganegaraan anak dan hambatan bahasa. Dalam hal ini, dapat disimpulkan bahwa perilaku keseharian menjadi sumber konflik.

Penemuan dari penelitian ini terdapat dampak yang diberikan oleh konflik yaitu adanya perilaku agresif terhadap pihak yang memiliki pemikiran yang berbeda. Dari pemaparan di atas, P1 
dan P2 memiliki konflik perilaku keseharian seperti selera makan dan disiplin tepat waktu. TJL dan TM mebawa kebiasaan sehari-harinya yang masih kurang bisa diterima oleh pasangannya. Hal ini di perkuat dengan teori identitas budaya yang memiliki tiga prinsip dasar salah satunya adalah identitas budaya bervariasi kekuatannya antarindividu (Hybels, Richard, \& Weaver, 2009)

Penemuan selanjutnya adalah sumber konflik yang dialami oleh TM dan AI (P2) adalah hambatan bahasa yang dibebankan kepada TM yang tidak dapat berbahasa Indonesia untuk berkomunikasi dengan keluarga besar AI. Keluarga AI pun tidak banyak yang dapat berbahasa inggris sehingga TM sedikit kesulitan untuk bersosialisasi dan mendekatkan diri dengan keluarga besar AI. Penemuan di atas sejalan dengan teori yang dijelaskan oleh Marger (2006). Marger menjelaskan lima karakteritik dasar identitas etnis, dari lima karakteristik tersebut salah satunya yang terkait dengan temuan adalah adanya cultural traits yaitu sifat budaya khas yang menjadi basis di kehidupan sosial seperti bahasa dan agama.

Konflik pada pasangan kedua, TJL menginginkan anak-anaknya untuk menjadi warga Negara Korea dengan alasan agar pendidikan mereka lebih mudah di Korea karena mereka akan dianggap Insider oleh pemerintahan Korea. Seperti yang dipaparkan oleh Borstein, negara dan bangsa membangun identitas nasional dengan menetapkan batas insider dan outsider, orang-orang yang di luar batas nasional dipandang sebagai berbeda pada dasarnya (Nanda \& Warms, 2012).

Temuan di pasangan kedua, TM dan AI memang selalu memiliki konflik namun dalam benak mereka berdua sangat tabu sekali untuk memikirkan hal seperti perceraian. Begitu pula dengan ND dan TJL, mereka memiliki konflik yang tidak mudah untuk di selesaikan namun tetap memilih untuk melanjutkan pernikahan mereka ketimbang memilih untuk cerai.
Penjelasan di atas di perkuat dengan pernyataan dari Indra Noveldy (2012), seorang konsultan pernikahan, dia menjabarkan bahwa terdapat 4 stadium dalam konflik rumah tangga. Namun di kedua pasangan ini hanya mencapai konflik stadium 1 saja. Konflik dapat diartikan sebagai individu yang memiliki pendapat berbeda yang dibalut dengan emosi dan kekecewaan terhadap individu lainnya, pada konteks ini perbedaan pendapat suami dengan istri. Konflik stadium 1 memiliki definisi sebagai konflik pada awal perbedaan pendapat dan masih mudah untuk diselesaikan.

Dikarenakan perasaan sayang dan keinginan untuk mencintai masih cukup besar terhadap pasangannya sehingga adanya konflik tersebut masih bisa dibicarakan dengan baik-baik. Salah satu dari individu yang sedang memiliki konflik tersebut masih dapat mengalah dan mengikuti kemauan dari pasangannya. Alasan lain mengapa konflik cepat redup adalah karena salah satu dari individu yang berkonflik tidak ingin mengkomunikasikan pendapatnya dikarenakan akan membuat pasangannya menjadi marah. Pola pikir pernikahan yang bahagia adalah pernikahan yang tidak memiliki konflik sama sekali, namun disini apabila dibiarkan terus menerus akan menimbun permasalahan dan bisa jadi lebih besar dari masalah sebelumnya.

Tahap percobaan (trial) terjadi pada pasangan pertama dan kedua. Pada pasangan pertama terdapat perbedaan dalam segi kebiasaan dalam memilih makanan, hal ini mencolok sekali di dalam terjadinya konflik. Pada pasangan kedua terdapat permasalahan kebiasaan ketepatan waktu yang menjadi hal mencolok dalam terjadinya konflik.

Teori yang memperkuat temuan tersebut adalah penjelasan dari Imahori dan Cupach (Littlejohn \& Foss, 2009) yang menjelaskan 3 tahapan pengelolaan identitas dalam hubungan. tahap pertama adalah tahap percobaan. Pada tingkatan 
trial, pasangan berbeda budaya hanya akan mencari perbedaan identitas kultur mereka yang diinginkan untuk disesuaikan oleh mereka. Permasalahan yang terberat pada tingkatan ini adalah menghindari perselisihan yang menjatuhkan dan saling berdiam diri seraya tetap mengatur identitas diri sendiri dan individu lain serta melihat bagian positif dan negatifnya yang dapat dikurangi, dihilangkan atau di pertahankan

\section{Cara Memanajemen Konflik}

Melanjutkan dari penjelasan Imahori dan Cupach (Littlejohn \& Foss, 2009) pada bagian sebelumnya menjelaskan bahwa bila sudah melewati tahap percobaan akan berlanjut pada tahap kecocokan.

Pada tingkatan emmeshment, identitas baru yang sudah disepakati terbentuk dengan memiliki norma dan budaya yang sama dengan kultur di masyarakat. Dalam hal ini, pasangan sudah menemukan kenyamanan dalam diri mereka dengan pasangannya masingmasing. Kedua individu mulai memberikan aturan dan simbol tertentu yang disetujui terkait dengan pemahaman antar individu dan hubungannya.

Pada tingkatan ini kedua pasang suami-istri sudah mengerti perbedaan yang terjadi pada individu masing-masing dan mencoba untuk mencocokan kedua kebiasaan mereka atau mengubah kebiasaan mereka ke arah yang lebih baik. Seperti yang di tunjukan pada pasangan pertama di permasalahan pemilihan menu makanan, TJL mencoba untuk memakan makanan khas Indonesia dan begitu juga ND yang mencoba untuk menghidangkan makanan Indonesia yang sekiranya cocok dilidah TJL.

Sedangkan pada pasangan kedua, AI lebih memilih mengubah kebiasaannya untuk belajar lebih tepat waktu, karena menurutnya hal tersebut lebih baik ketimbang kebiasaannya yang suka mengulur-ulur waktu.
Keluarga menciptakan realitas bersama melalui dua perilaku komunikasi: orientasi percakapan dan orientasi kepenurutan. Orientasi percakapan adalah komunikasi yang terbuka antara orang tua dan anak-anaknya dengan tujuan untuk menggali bersama lambang-lambang dan objek dalam lingkungan sosial keluarga. Orientasi kepenurutan lebih mengarah kepada komunikasi yang terbatas antara orang tua dan anak di mana orang tua memegang wewenang dalam mengambil keputusan.

Secara teoritis bersilangan, kedua orientasi tersebut mendefinisikan ruang konseptual dengan 4 tipe keluarga. Pertama, keluarga bermufakat berperingkat tinggi pada orientasi percakapan dan orientasi kepenurutan. Kedua, keluarga majemuk cenderung lebih memilih orientasi percakapan ketimbang orientasi kepenurutan. Ketiga, keluarga terlindung menekankan orientasi kepenurutan ketimbang orientasi percakapan. Keempat, keluarga terserah berperingkat rendah baik di orientasi kepenurutan dan orientasi percakapan (Berger, Roloff, \& Roskos-Ewoldsen, 2014).

Terdapat perbedaan tipe keluarga dari kedua pasangan yang sudah diteliti. Terlihat di pasangan pertama lebih mengacu pada keluarga bermufakat karena ketika menyelesaikan masalah keduanya berdiskusi dan menemukan titik tengah di mana keduanya dapat menyetujui pilihan tersebut dan menerapkan hal yang sudah disepakati. Untuk pasangan kedua terdapat diantara keluarga majemuk dan keluarga terlindung, namun cenderung lebih mengarah pada keluarga terlindung. Hal ini terlihat pada penyelesaian masalah yang diperlihatkan oleh AI bahwa dia lebih menuruti kata-kata TM walaupun sekalisekali AI ngeles tentang permasalahan ketepatan waktu.

Seperti yang di jelaskan di atas, menurut Maier dan Solem terdapat tiga langkah untuk menyelesaikan masalah; 
identifikasi masalah, menentukan solusi yang tepat, dan memverifikasi solusi yang sudah dihasilkan (Borisoff \& Victor, 1989).

Identifikasi masalah adalah langkah pertama yang penting untuk mengetahui masalah yang sedang terjadi. Di beberapa contoh pasangan, masalah tidak terlihat atau lebih mudahnya tertutup di bawah permukaan dalam kehidupan hubungan suami-istri. Misalnya istri bekerja lebih keras ketimbang suami dan karena itu pekerjaan rumah tangga tidak dibebankan kepada istri melainkan ditanggung seluruhnya oleh suami. Suami pun merasa bahwa posisinya lebih penting dan menolak untuk melakukan pekerjaan rumah tangga.

Contoh kasus yang didapatkan dari kedua pasangan adalah masalah dikeduanya tidak tertutup sehingga lebih mudah untuk menemukan solusi yang pas terhadap masalah yang sedang dihadapi. Kedua pasangan saling terbuka ketika ada konflik yang menghampiri, mereka menyatakan dengan jelas apa yang sedang dihadapi.

\section{Resolusi yang Dihasilkan Setelah Konflik Selesai}

Diawali dengan penjelasan dari Gottman (Berger et al., 2014), ia mendapati bahwa perilaku selama interaksi konflik sangat prediktif bagi stabilitas dan kepuasan hubungan, dalam satu studi dengan akurasi $80 \%$ untuk kepuasan dan $83 \%$ untuk stabilitas setelah 6 tahun. Yang terutama perilaku yang mengungkapkan perasaan negatif kepada pasangan, seperti kritik, sikap membela diri, penghinaan, dan penarikan diri, bisa memprediksikan ketidakpuasan dan perceraian.

Namun pembahasan selama konflik tidak melulu tentang perasaan negatif. Setidaknya dalam satu studi, Gottman mendapati bahwa hanya pengungkapan perasaan positif kepada pasangan yang memprediksikan stabilitas dan kepuasan pernikahan dari waktu ke waktu. Efek positif ini ditemukan pada kedua pasangan. Efek positif yang didapatkannya juga dari pasangan pertama adalah konflik yang sudah selesai dapat dijadikan alat untuk mengintrospeksi diri dan komitmen yang dibuat untuk menjadi lebih baik kedepannya. Sedangkan efek yang didapatkan pada pasangan kedua adalah hasil dari konflik tersebut dapat dijadikan alat untuk mengeluarkan isi hati dan keluhan yang mengganjal terhadap pasangannya.

Seperti yang didapatkan dari temuan di atas bahwa kedua pasangan tersebut walaupun memiliki konflik yang pelik, keduanya bisa melihat efek positif yang ditemukan setelah konflik tersebut berhasil dilewati. Buktinya dari pernyataan kedua pasangan tersebut masih memilih untuk tetap melanjutkan pernikahan mereka.

Konflik tidak dapat dihindari dalam hubungan intim dalam bentuk perselisihan, ketidaksukaan, saling berargumen dan ketegangan. Ini bisa menghasilkan hubungan yang tetap harmonis jika ditangani dengan baik atau hubungan yang buruk yang bisa berujung pada perceraian bila tidak ditangani dengan baik. Hal ini diasumsikan dari bukti empiris konflik yang terjadi pada pasangan yang berhubungan baik dan berhubungan buruk namun perilaku untuk mengelola konflik ini bervariasi di antara kedua pasangan tersebut.

Cara yang konstruktif untuk menangani konflik dalam hubungan pernikahan akan memfasilitasi hubungan dengan baik namun sebaliknya jika cara destruktif dalam penanganan konflik akan menjadikan hubungan yang penuh tekanan dan terdisfungsi (Dildar et al., 2013). Beruntungnya, kedua pasangan tersebut menunjukan cara penanganan konflik yang konstruktif. Hal ini diperlihatkan dengan bagaimana mereka menghadapi konfliknya dan mendapatkan efek positif dari konflik tersebut. Sebut saja pada pasangan pertama, TJL tidak begitu menyukai 
makanan Indonesia namun ND membuatkan makanan Indonesia yang dapat diterima oleh lidah TJL. Pada pasangan kedua, AI yang masih terbiasa hidup tidak tepat pada waktunya, tepat waktu yang dimaksud adalah persiapan yang mendekati waktu yang ditentukan, sedikit demi sedikit belajar untuk bersiap lebih awal agar tidak dikejar oleh waktu dalam bersiap. Hal tersebut membuat efek positif pada hubungan dipasangan masingmasing.

Melanjutkan teori yang di jelaskan oleh Maier dan Solem, setelah masalah teridentifikasi tiap individual dapat mencoba untuk mengusulkan sebuah solusi. Pentingnya dalam proses pengelolaan konflik, keduanya harus saling bekerja sama adalah sebuah cerminan keprihatinan dari kedua belah pihak. Untuk lebih lanjutnya, solusi tentatif ini harus diartikulasikan secara terbuka namun tetap menggunakan cara nonevaluatif. Contohnya, suami yang bersikeras melakukan urusan tentang mencuci pakaian tidak harus mengurus bagian menyiapkan makanan atau mencuci piring. Demikian pula, bila istri ingin berhenti dalam membersihkan piring setidaknya membantu dalam menyiapkan makanan.

Dari kasus yang ditemukan dikedua pasangan, mereka bekerja sama saling mengusulkan solusi agar pernikahan mereka masih tetap berlanjut dan bertahan sampai saat ini. Walaupun pada pasangan pertama pengusulan solusinya terhitung cukup lambat namun mereka tetap bisa bekerja sama dengan baik untuk menyelesaikan masalahnya tidak seperti pasangan kedua yang terhitung cepat dalam memberikan solusi dalam menyelesaikan masalah.

\section{Penghindaran Konflik yang Dilakukan}

Setelah melewati kedua tahap tersebut, kedua pasangan sudah mencapai tahap ketiga yang dijelaskan oleh Imahori dan Cupach (Littlejohn \& Foss, 2009) yaitu tahap negosiasi ulang.

Pada tingkatan renegotiation, antar individu sebagai pasangan suami-istri memulai petualangan berbagai permasalahan terkait dengan identitas dan budaya yang sudah disepakati sebelumnya dan sudah dikembangkan oleh mereka sebagai pasangan suami-istri. Pada saat ini mereka sudah memiliki hubungan yang kokoh dan mampu menjadikan hubungan mereka lebih kuat lagi daripada waktuwaktu sebelumnya. Perbedaan identitas dan kultur yang muncul ke permukaan akan lebih mudah diselesaikan karena sudah ada pengalaman sebelumnya yang membuat mereka lebih dewasa dalam menghadapi perbedaan tersebut.

Pada kedua pasangan tersebut memiliki konflik yang sering terulang namun di kedua pasangan itu sudah menemukan cara untuk menyelesaikan konfliknya terlebih lagi dapat menghindari konflik yang sudah terjadi. Seperti di pasangan pertama, ND sebisa mungkin untuk menghidangkan masakan Indonesia yang TJL suka, begitu pula TJL yang berusaha untuk menyukai masakan Indonesia agar masakan yang sudah dibuat ND tidak mubazir.

Begitupun pasangan TM dan AI, AI masih suka mengulur waktu yang membuat TM jengkel karena kebiasaannya. Walaupun begitu, AI berusaha semampunya untuk mengubah kebiasaan buruknya yang sering mengulur waktu.

Tehranian dan Chappell (Ishii, 2008) menyimpulkan bahwa globalisasi telah mengantarkan nilai budaya yang berbeda ke dalam kontak langsung dan kadang kala menimbulkan konflik antarbudaya. Untuk menyelesaikan konflik tersebut bukanlah dengan cara saling beradu, namun untuk tercapainya perdamaian manusia saatnya diperlukan untuk membuka semua saluran komunikasi untuk proses dialog, negosiasi, dan penciptaan nilai-nilai yang sepadan dengan tantangan zaman kita sendiri. Oleh 
karena itu, sangat dibutuhkan dialog yang baik untuk menghindari konflik antarbudaya.

Dengan saling bekerja sama dan menjalankan komitmen yang sudah disetujui, keduanya memiliki cara untuk menghindari konflik, contohnya pada pasangan pertama, ND berusaha untuk membuatkan makanan yang cocok pada lidah TJL dan TJL juga berusaha untuk menyukai makanan Indonesia. Di pasangan kedua AI berusaha untuk tepat waktu agar TM tidak kembali membuat sebuah konflik dalam rumah tangga mereka.

Melanjutkan dari penjelasan sebelumnya dari Maier dan Solem, terakhir dalam pengelolaan konflik tidak berakhir karena memiliki kesepakatan bersama. Sama pentingnya dengan bagaimana individual tersebut memilih untuk berurusan dengan solusi untuk masalah yang gagal dalam memenuhi harapan atau kebutuhan mereka. Pihak yang tidak terima akan menggunakan taktik komunikasi defensif, misalnya tuduhan, prasangka buruk, mengancam, atau dengan stereotip adalah pilihan yang tepat untuk menemukan ucapan yang bersifat melawan dengan perilaku buruk dan perlawanan yang setara.

Sebaliknya bila dari individu tersebut menggunakan startegi komunikasi deskriptif ketika menyatakan perasaan mereka mungkin untuk menemukan kepedulian dari kedua belah pihak. Dengan demikian, misalnya masalah yang timbul terdapat pada biaya membeli makanan, dengan mengakui sumber masalah tersebut dan adanya kemauan untuk bekerja sama untuk menemukan solusi yang baru, ini akan jauh lebih memungkinkan untuk memulai interaksi yang lebih produktif daripada dalam suasana yang dibebankan dengan tuduhan dan perilaku defensif

Pada pasangan pertama, TJL yang tidak begitu menyukai masakan Indonesia oleh karena itu ND membuatkan makanan
Indonesia namun yang cocok di lidah TJL. Di sisi TJL pun berusaha untuk menyukai makanan Indonesia karena untuk mencari makanan Korea tidak semudah menemukan makanan Indonesia. Sedangkan pada pasangan kedua, walaupun AI kurang menyetujui untuk siap diwaktu yang lebih awal, siap dalam waktu 1 jam sebelum jadwal yang ditentuka misalnya, namun dia berusaha untuk menyetujui hal tersebut karena disatu sisi, hal ini membuat AI tidak terburu-buru ketika terjadi hal di luar perkiraan, disisi lain hal ini tidak menjadikan alasan untuk memulai sebuah konflik yang baru.

\section{SIMPULAN}

Konflik yang muncul dalam pernikahan beda kewarganegaraan disini adalah konflik dari internal dan eksternal. Berbagai konflik sebenarnya banyak yang terjadi namun disini dipilih konflik yang terbesar dari setiap pasangan pernikahan beda kewarganegaraa.

Dari bagian internalnya adalah permasalahan makanan Indonesia dari pihak keluarga individu berkebangsaan luar, masalah kedisiplinan karena untuk individu berkebangsaan amerika selalu memegang teguh bahwa "waktu adalah uang" sehingga mereka selalu tepat waktu, dan pilihan makanan Indonesia yang berbeda dengan kebangsaan luar menjadikan permasalahan tersendiri bagi pasangan tersebut;

Sedangkan untuk konflik bagian eksternalnya adalah peliknya penentuan kewarganegaraan anak karena melibatkan anggota keluarga besarnya serta permasalahan bahasa dari pihak kebangsaan luar Indonesia yang tidak dapat berkomunikasi secara lancar dengan anggota keluarga pihak kebangsaan Indonesia.

Selanjutnya adalah resolusi yang dilakukan oleh kedua pasangan berakhir dengan hasil tetap melanjutkan pernikahan mereka. Dengan komitmen 
yang sangat kuat dan rasa cinta yang begitu besar dapat mengalahkan konflik yang menimpa mereka.

Gaya penyelesaian konflik dari kedua pasangan tersebut adalah yang pertama akan membicarakan konflik yang terjadi pada hari itu agar selesai di hari itu juga dengan hasil yang keduanya merasa puas dengan hasil yang didapatkan atau salah satu dari mereka tidak puas dengan hasil yang ada dan menerima dengan lapang dada ataupun membalas dengan menimbulkan konflik namun berbeda dengan konflik yang pertama. Dapat disimpulkan bahwa resolusi dari pasangan ini adalah dengan mendiskusikan secara langsung agar konflik dapat selesai pada hari yang sama;

Pada pasangan yang kedua dalam menyelesaikan konflik adalah dengan menunda konflik yang sedang terjadi namun tidak sepenuhnya dilupakan terkait dengan kewarganegaraan anak karena hak memilih untuk menjadi warga Negara mana itu sepenuhnya berada ditangan anak. Dengan menanyakan alasan mengapa memilih untuk menjadi warga Negara tersebut dapat dijadikan jawaban terhadap keluarga besar dari individu berkebangsaan luar untuk menyetujui pilihannya. Walaupun tidak sepenuhnya argumen tersebut dapat mempengaruhi keluarga besar individu kewarganegaraan luar setidaknya mereka memiliki pembelaan bila tidak disetujui. Maka resolusi dari pasangan ini adalah menunda konflik namun tetap menjadi prioritas utama.

\section{DAFTAR PUSTAKA}

Abdul \& et.al, (1989). al-Islam. Malang, Pusat Dokumentasi dan Publikasi Universistas Muhammadiyah, Jilid I.

Arikunto (2002). Metodologi penelitian. Jakarta: PT. Rineka Cipta.

Berger, R, \& Roskos-Ewoldsen (2014). Handbook Ilmu Komunikasi

Borisoff \& Victor (1989). Conflict management: A communication skills approach. Englewood Cliffs, NJ: Prentice Hall.
Dildar, Sitwat, \& Yasin (2013). Intimate enemies: Marital conflicts and conflict resolution styles in dissatisfied married couples. Middle-East Journal of Scientific Research, 15(10), pp.1433-1439.

Donsbach \& Donsbach (2008). The international encyclopedia of communication. Wiley Publishing.

Fithria (2011). Hubungan Komunikasi Keluarga Dengan Konsep Diri Remaja. Idea Nursing Journal, 2(1)

Esere (2003). Resolving Conflicts in Marriages: A Counsellor's Viewpoint.

Holt (2004). 'Marriage-Like'or Married? Lesbian and Gay Marriage, Partnership and Migration. Feminism \& Psychology, 14(1)

Hybels, R. \& Weaver (2009). Communicating effectively.

Interracial Marriage and Relationships: A Fact Sheet. | National Resource Center for Healthy Marriage and Families. (n.d.). DiperolehOktober 13, 2017, dari https://www.healthymarriageandfamilies.or g/library-resource/interracial-marriageand-relationships-factsheet?backtolib $=0$ \&page $=205$

Ishii (2008). Promoting Interreligious Communication Studies: A Rising Rationale Human Communication.A Publication of the Pacific and Asian Communication Association. Vol. 11

Kusmarni (2012).Studi Kasus. UGM Jurnal Edu UGM Press.

Kompas Lifestyle. (2012, May 18). Begini Konflik Pernikahan Bermula! Kompas.Com. Diperoleh November 1, 2017, darihttps://lifestyle.kompas.com/read/2012 /05/18/12053840/Begini.Konflik.Pernikaha n.Bermula

Lainiala \& Säävälä (2013). Intercultural marriages and consideration of divorce in Finland: Do value differences matter. The population research institute. Accessed, 10

Lewis (2013). Status of Interracial Marriage in the United States: A Qualitative Analysis of Interracial Spouse Perceptions. International Journal of Social Science Studies, 2(1)

John. L. \& Foss (2009). Teori komunikasi. Jakarta: Salemba Humanika.

Luther\& Rightler-McDaniels (2013). More Trouble than the Good Lord Ever Intended: Representations of Interracial Marriage in US News-Oriented Magazines. Journal of Magazine \& New Media Research, 14(1)

Marger (2003). Race and ethnic relations: American and global perspectives. Belmont, CA: Wadsworth/Thomson Learning. 
Mackey \& O’Brien (1998). Marital conflict management: Gender and ethnic differences. Social Work, 43(2)

Magnuson-Canndy (2005). "My Daughter Married a Negro": Interracial Relationships in the United States as Portrayed in Popular Media, 1950-1975.UW-L Journal of Undergraduate Research VIII

Miller, Roloff, \& Malis, (2007). Understanding interpersonal conflicts that are difficult to resolve: A review of literature and presentation of an integrated model. Annals of the International Communication Association, 31(1)

Moleong (2000). Metodologi Penelitian Kualitatif. Bandung: PT. Remaja Rosdakarya.

Moleong (2011). Metodologi Penelitian Kualitatif Edisi Revisi. Bandung: PT. Remaja Rosdakarya.

Morris (2003). Alienation and Isolation in Interracial Marriages in East Tennessee.Electronic Theses and Dissertations. Paper 808.
Nanda \& Warms (2012). Cultural anthropology. Cengage Learning.

Priandono (2014). Komunikasi Keberagaman. Bandung: Remaja Rosdakarya

Pue \& Sulaiman (2013)"Choose One!": Challenges of Inter-Ethnic Marriages in Malaysia. Asian Social Science, 9(17)

Puspitawati (2013). Konsep dan Teori Keluarga.

Rahardjo (2017). Studi kasus dalam penelitian kualitatif: konsep dan prosedurnya.

Sendjaja (2014). Pengantar Ilmu Komunikasi.

Sillars et al, (1997). Relational characteristics of language: Elaboration and differentiation in marital conversations. Western Journal of Communication (includes Communication Reports), 61(4).

Sugiyono, D. (2013). Metode penelitian kuantitatif kualitatif dan R\&D. Penerbit Alfabeta.

Hybels, R \& Weaver (2009). Communicating effectively.

U. U. (1). tahun 1974 tentang Perkawinan, 1974.

Zhang \& Hook, V. (2009).Marital dissolution among interracial couples. Journal of Marriage and Family, 71(1). 